\title{
The effects of anthropogenic landscape change on the abundance and habitat use of terrestrial large mammals of Nech Sar National Park
}

\author{
Aaramde Fetene*, Kumelachew Yeshitela and Ephrem Gebremariam
}

\begin{abstract}
Background: Landscape change and disturbance are major challenges of wildlife management worldwide. The purpose of this study is to determine the impacts of anthropogenic landscape disturbances on the abundance and habitat use of terrestrial large mammals of Nech Sar National Park. Disturbance of natural habitats for 1985, 1995, 2005 and 2013 was analyzed using descriptive metrics of different landscapes at the class level. Population estimates of large terrestrial mammals were conducted using the line-transect method. Data were collected on the distribution and abundance of human settlement, domestic animals' sightings and livestock Karel using field observation and Google Earth digital image.

Result: The results have shown that anthropogenic disturbances lead to changes in the size, number, distance, spatial distribution and configuration of fragments in the natural habitats between 1985 and 2013. The highest anthropogenic impacts are detected on the forest and grassland habitats through fuelwood and construction wood collection, settlement and overgrazing. Large concentrations of settlement with grass-roofed and tin-roofed houses are observed in the grassland and wooded grassland habitats. Out of the recorded 1079 houses built within the park, 867 (80.4\%) were mud and wood wall with grass-roofed and 212 (19.6\%) were tin-roofed houses. The ratio of tin-roofed and grass-roofed houses is 0.24:1 which suggests the permanency of human settlement and the high intensity of human impact on the wildlife. About 771 cattle Karels were recorded with the ratio of Karel to house as 0.89:1 which indicates that households have at least one Karel near to their residence. These habitat disturbances have resulted in the decline of key wildlife species in Nech Sar National Park. For instance, the population of Grant's zebra (Equus quagga) has decreased from 6500 in 1985 to 2161 in this study based on the 2013 count. The population of Swayne's hartebeest (Alcelaphus buselaphus swaynei) has significantly decreased in the past decades from 40 in 1992 to 35 in 2008, to 12 in 2010, to four (4) in 2013 and locally extinct between 2017 and 2018 based on the Nech Sar National Park office information.

Conclusions: Human activities in the Nech Sar National Park are the root causes for the decline of key wildlife species particularly for the loss of Swayne's hartebeest in the park over the past three decades. These changes are mainly related to habitat loss and habitat fragmentation due to deforestation, livestock overgrazing and residential expansion (tin-roofed, grass-roofed houses). Therefore, the main priority in Nech Sar National Park should be designing management strategies to restore the park as a fully functioning sustainable ecosystem and ensuring the social and economic sustainability of the local community. This intervention can be addressed by creating other means of livelihood,
\end{abstract}

\footnotetext{
*Correspondence: aramde.fetene@eiabc.edu.et
}

Ethiopian Institute of Architecture, Building Construction and City

Development (EiABC), Addis Ababa University, P.O. Box 518, Addis Ababa, Ethiopia 
supplying alternative energy, establishing basic infrastructure and relocating the community out of the park. In this regard, a resettlement action plan should be prepared that could ensure the community will not come back to the protected area for livelihood.

Keywords: Disturbance, Habitats, Landscape metrics, Population, Wildlife

\section{Background}

Protected areas (PAs) are increasingly perceived as crucial for biodiversity conservation (Nandy et al. 2015) and an effective solution to ensure the protection of ecosystems (Bruner et al. 2001). However, in many developing countries they do not achieve that conservation goal as the landscapes within and around them are degraded at an unprecedented speed and scale with a complex response to several human-induced changes (Nagendra and Rocchini 2008). Hence, landscape change and disturbance are major challenges of wildlife management worldwide (Kaly et al. 2002; Southworth et al. 2002; Haddad et al. 2015) which influence the distribution, abundance and density of wildlife population (Hockin et al. 1992; Baillie et al. 2004; Blom et al. 2004), altering various aspects of activity patterns (Kilpatrick and Lima 1999; Presley et al. 2009), creating stress on their habitat use (Coulon et al. 2008; Fletcher and Hutto 2008; Markovchick-Nicholls et al. 2008), and disrupting reproductive success along with energy budget (Hockin et al. 1992).

In many protected areas, numerous wildlife species are vulnerable to extinction because of anthropogenic habitat modifications (Estrada et al. 2012). As human activities increase in natural areas, wildlife habitats tend to show loss or fragmentation, negatively affecting the species distribution, activity, reproduction and survival (Wiens 1990; Ceballos and Ehrlich 2002). Thus, habitat destruction has been targeted as one of the most serious threats to biological diversity (Wilcove et al. 1998), which in turn can result in the loss, fragmentation and reduction of ecosystem functionality (Cardinale et al. 2006; Folke et al. 2004). Furthermore, fragmentation and loss of natural habitats are now recognized as major challenges to wildlife conservation (Fahrig 1997). As rates of habitat destruction continue to rise, investigating the principal underlying causes and consequences of fragmentation could be a fundamental tool to the effective management and conservation of protected areas (Nagendra 2001; Said et al. 2016). Moreover, study of landscape structure and configuration as well as the impacts of landscape change on the wildlife population and habitat use is a fundamental tool to design strategies to restore the ecosystem into a condition of sustainability and could be an integral part of conservation planning (Saberwal and Chhatre 2003; Folke et al. 2004). To that end, assessing the impact of anthropogenic landscape change and landscape disturbance on wildlife requires systematically collected data on the human activities within the protected area, habitat loss and fragmentation, abundance and habitat use of wildlife species and the influence of a changing and disturbed landscape on key wildlife species (Southworth et al. 2002; Ogutu et al. 2009).

Nech Sar National Park (NSNP) is one of the protected areas in Ethiopia principally established to conserve the endangered Swayne's hartebeest (Alcelaphus buselaphus swaynei) with other big games along with the landscape (Bolton 1973; Duckworth et al. 1992). Although, NSNP was established as crucial to protecting key wildlife species and habitats (Blower 1968; Bolton 1971), for the past couple of years, the habitats at NSNP have been seriously threatened by human-induced impacts (Svialek 2008; Kelboro and Stellmacher 2012; Kelboro et al. 2013).

Thus, the main aim of this study is to answer the questions related to the extent of landscape change and its impact on the abundance and habitat use of terrestrial large mammals therein. In this regard, the specific objectives were: (i) to determine the habitat quality mainly in terms of habitat configuration (patch size and isolation) and habitat continuity; (ii) to examine the abundance and habitat use of terrestrial large mammals; (iii) to examine the intensity and distribution of human activities and their impacts on key wildlife species across the different habitat types of NSNP.

\section{Materials and methods \\ Study area}

NSNP was selected as a unit of study because it is one of the protected areas of Ethiopia established based on the International Union for Conservation of Nature (IUCN) category II conservation criteria to protect the big games with the landscape (Duckworth et al. 1992), but now is critically degraded due to anthropogenic interferences (Kelboro and Stellmacher 2012). NSNP covers an area of about $514 \mathrm{~km}^{2}$ and is located $510 \mathrm{~km}$ south of Addis Ababa with an altitudinal range of $1100-1650 \mathrm{~m}$ above sea level (Fig. 1).

The landscape of the park is a mosaic of savannah grasslands, hill areas, lakes, riparian and groundwater forest, woodlands, bush and thickets (White 1983; Duckworth et al. 1992). The groundwater forest and Kulfo riparian forest dominate the western part of NSNP and the Sermele riparian forest is found in the eastern part of 


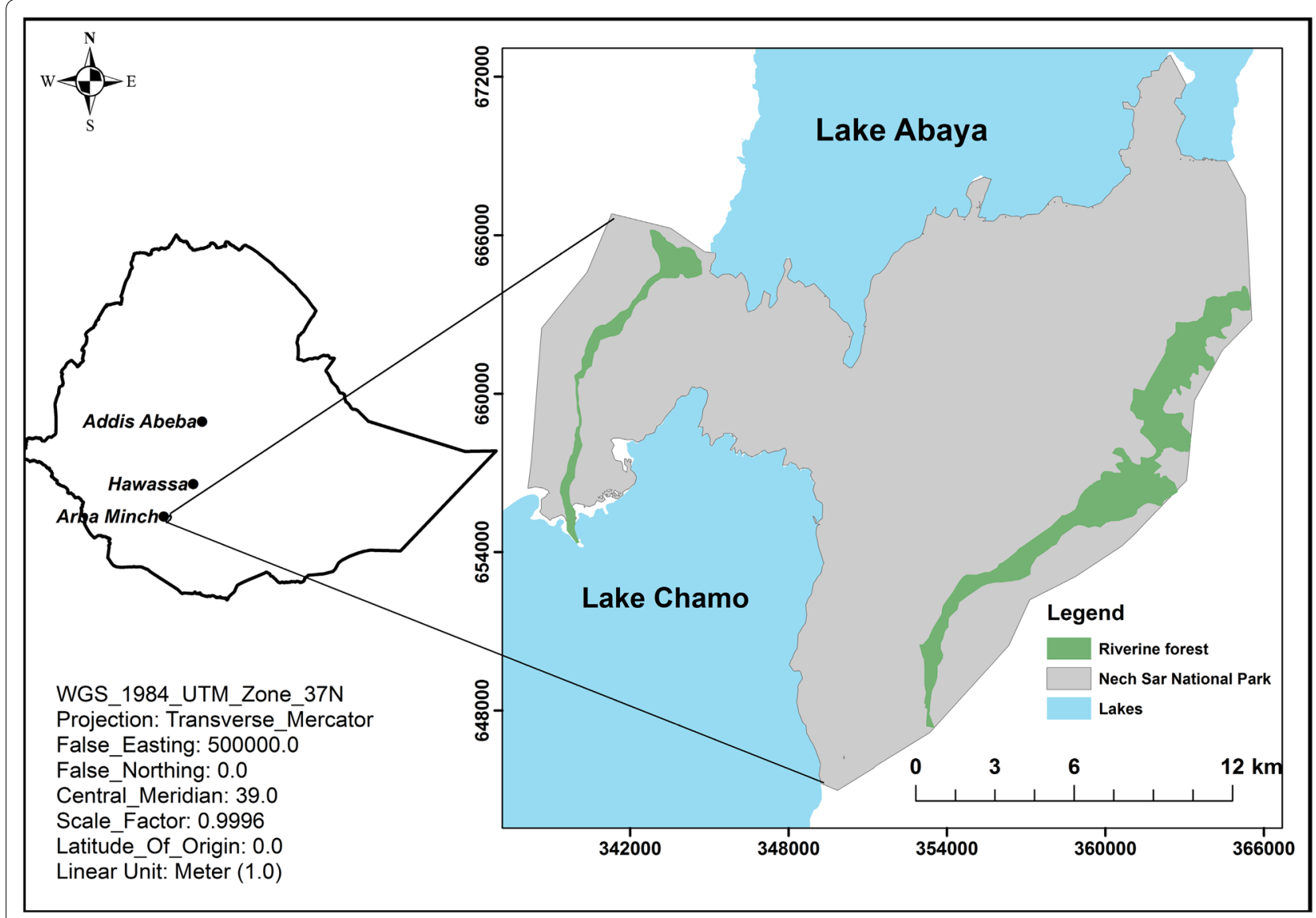

Fig. 1 Map of the study area showing different geographical features

the park along the Sermele River. The park includes terrestrial (85\%) and aquatic (15\%) habitats (Clark 2010) but the scope of this study is limited to the park's terrestrial habitats due to the multiple problems associated with the park's management and conservation.

The climate of the study area is characterized by a relatively hot climatic condition with low and unevenly precipitation distribution. Based on the information from the National Metrological Agency of Ethiopia, the mean annual minimum and maximum temperature of the area was reported as $17{ }^{\circ} \mathrm{C}$ and $30.2{ }^{\circ} \mathrm{C}$, respectively and the average annual rainfall was $907 \mathrm{~mm}$. As is common in semi-arid areas (Moss 2005), the distribution of rainfall around the study area is highly variable from year to year. Precipitation falls mainly during a longer rainy season ('long rains') in March, April, and May and a second, shorter rain season 'short rain' between September, and November.

\section{Data source and analysis}

The main data sources for this research were the shapefiles derived from the Landsat images of NSNP for the periods of 1985, 1995, 2005 and 2013, direct field-based wildlife survey, assessment of human activities in the field and discussions with the park management office. From the shapefiles, five terrestrial natural habitats were derived which are compatible with the objectives of this study. These wildlife habitats include: forest, shrubland, wooded grassland, woodland, grassland, and their definitions are described below based on FAO (2012) and White (1983:46).

\section{Derivation of landscape metrics and detecting change statistics}

In order to describe the overall landscape changes over time, the vector data from the habitats' shapefiles were converted to raster format with a pixel size of $30 \mathrm{~m} \times 30 \mathrm{~m}$ using the ArcMap Spatial analyst tool. Accordingly, landscape metrics were grouped into categories of CA (Class area), PLAND (Percentage of Land), NP (Number of patch), MPS (Mean Patch Size), IJI (Interspersion and juxtaposition index), MNN (Mean near neighbor distance) and Mean Patch Fractal Dimension (MPFD) (Tables 1,2) and their statistics were calculated 
Table 1 Land cover description of Nech Sar National Park

\begin{tabular}{ll}
\hline Land cover class & Description \\
\hline $\begin{array}{l}\text { Forest } \\
\text { Land spanning more than } 0.5 \mathrm{ha} \text {, with a tree canopy cover of more than 10\%, which is not primarily under agricultural or urban } \\
\text { land use and includes forest in national parks, nature reserves and other protected areas such as those of specific environmental, } \\
\text { scientific, historical, cultural or spiritual interest }\end{array}$ \\
$\begin{array}{l}\text { Area covered by woody perennial plant, generally more than } 0.5 \mathrm{~m} \text { and less than } 5 \mathrm{~m} \text { in height at maturity and without a definite } \\
\text { crown. The height limits for trees and shrubs should be interpreted with flexibility, particularly the minimum tree and maximum } \\
\text { shrub height, which may vary between } 5 \text { and } 7 \mathrm{~m}\end{array}$ \\
$\begin{array}{l}\text { Wooded grassland } \\
\text { Loodland } \\
\text { Consists of trees that are branched, deciduous and range from } 8 \text { to } 20 \text { m in height, canopy cover }>20 \%, \text { crowns may touch grasses } \\
\text { and herbs present } \\
\text { Land covered by grasses and other herbs, either without woody plants or if present not covering more than 10\% of the ground }\end{array}$ \\
\hline
\end{tabular}

Table 2 Selected landscape metrics following the definitions of McGarigal and Ene (2012)

\begin{tabular}{|c|c|c|}
\hline Spatial metrics & Abbreviation & Description \\
\hline Core area & CA & $\begin{array}{l}\text { Class area is a measure of landscape composition; specifically, how much of the landscape is } \\
\text { comprised of a particular patch type where the range is explained by CA }>0\end{array}$ \\
\hline Percent of landscape & PLAND & Measures habitat extent in relative terms of the target land cover class $(0<P L A N D<100)$ \\
\hline Number of patches & NP & Number of patches in the landscape of the same LULC class $(N \geq 1)$ \\
\hline Mean patch size & MPS & $\begin{array}{l}\text { It measures the average mean surface of patches and it is used to evaluate landscape fragmen- } \\
\text { tation }\end{array}$ \\
\hline Interspersion and juxtaposition index & | & $\begin{array}{l}\text { Measure of evenness of patch adjacencies equals } 100 \text { for even and approaches } 0 \text { for uneven } \\
\text { adjacencies }\end{array}$ \\
\hline Mean near neighbor distance & MNN & Measures the degree of isolation and fragmentation of a patch \\
\hline Mean patch fractal dimension & MPFD & $\begin{array}{l}\text { Measures the shape complexity. Mean fractal dimension approaches one for shapes with simple } \\
\text { perimeters and approaches two when shapes are more complex }\end{array}$ \\
\hline
\end{tabular}

using the software FRAGSTATS 4.2.1 (McGarigal and Ene 2012) for the periods of 1985, 1995, 2005 and 2013. This analysis is an effective method of detecting changes in continuity, fragmentation, and aggregation of different habitats over time (MacLean and Congalton 2015).

These metrics were considered because they are some of the most frequently cited as ecologically important landscape metrics (Paton 1994; Haines-Young and Chopping 1996; Bender et al. 1998). In order to determine the disturbance of natural habitats, descriptive metrics of different landscapes were compared at the class level.

\section{Wildlife survey design}

The study area was stratified into three main census zones based on the main vegetation types, the topography, degree of land use effect and the landscape under consideration (Fig. 2).

The Arba Minch ground water forest, the Kulfo riparian areas and associated woodlands and shrublands in the western part of the park was considered as zone one, the central hilly and undulating area between the two lakes (Abaya and Chamo) locally known as the God's bridge and dominantly covered by shrubland was considered as zone two and the open grassland in Nech Sar plain along with the Sermele riparian area with the associated woodlands and wooded grasslands was considered as zone three.

Sample counts were made to estimate the population size of large terrestrial mammals in the study area (Grimsdell 1978; Norton-Griffiths 1978) using the linetransect method which was designed based on series of straight-line segments (Anderson et al. 1978). As the landscape in NSNP is not homogeneous, the number and the transect lengths in each of the census zones varied depending on terrain condition, the shape of the study area and vegetation distribution (Frankyates 1971; Burnham et al. 1980; Ndhlovu and Balakrishnan 1991). A total of 44 parallel transects were evenly spaced in the study area (Durant et al. 2011) and located to represent 20-25\% of each of the surveyed areas which considered five major habitat types of NSNP (Megaze et al. 2012; Betts et al. 2003). The length of transects varied from 2 to $7 \mathrm{~km}$ and a total of $186 \mathrm{~km}$ distance was covered. Consecutive transects were spaced at a distance of $2 \mathrm{~km}$. On the specified transect lines, the coordinates of the beginning and the ending of transects were generated with ArcGIS in advance and the study team carefully followed the survey design using a global positioning system (GPS). 


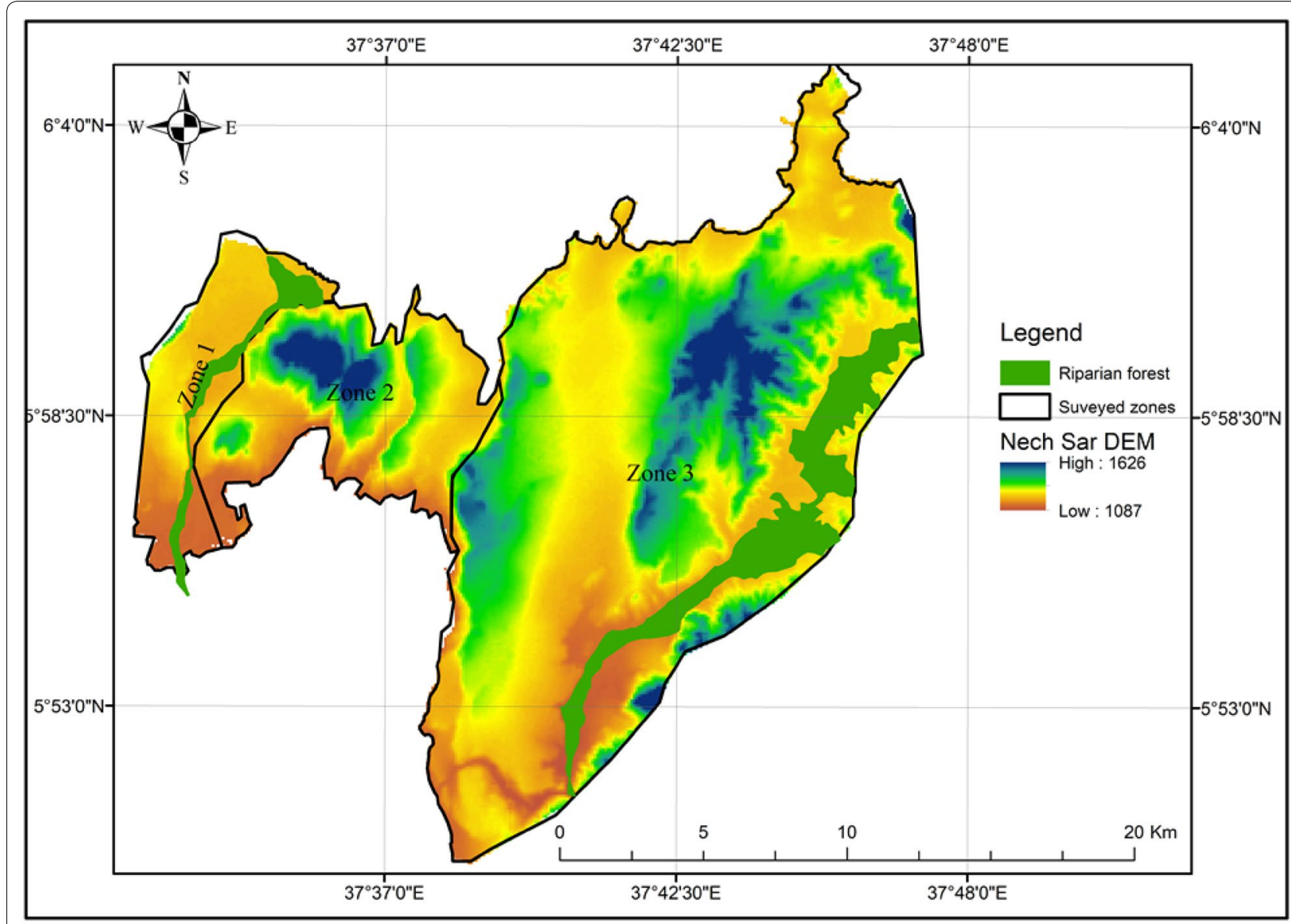

Fig. 2 Stratified zones for wildlife survey

\section{Population estimate}

The scope of population estimate was limited to large terrestrial mammals of NSNP with an approximated mass of greater than $5 \mathrm{~kg}$ (Njoroge et al. 2009; Craigie et al. 2010; Scholte 2011), having diurnal activity pattern and qualify as focal species for management as it is likely that their minimum habitat requirements will also be adequate for the conservation of other biotas (Wilcox 1982). Moreover, the distribution and spatial requirement of the larger mammals are easier to monitor, than those of the smallsized mammals and therefore more appropriate for effective control of conservation measures. Thus, population survey along the transects was conducted systematically with the help of trained and experienced wildlife technicians during wet and dry seasons at a constant speed to maximize the probability of seeing all individuals on the transect (Norton-Griffiths 1978). During sample count, each individual was considered as a group member of the same herd if the distance between them was less than $50 \mathrm{~m}$ (Borkowski and Furubayashi 1998), responded in a related manner to external stimuli and if moving in the same direction with the rest of the members of the herd (Lewis and Wilson 1979).

Population abundance and density were calculated using the software "DISTANCE" Version 6 Buckland et al. (1993). The general guidelines of Buckland et al. (1993) were followed in data preparation and analysis and hence for better density estimates using DISTANCE analysis, the number of sighting should be $>60$ observations. Thus, in this study for sightings of wildlife with few observations, estimation of abundance was not considered by distance analysis, rather for the rare species like Swayne's hartebeest total count method was employed (Sutherland 2006).

The mean of individuals observed per transect for the most abundant species (i.e. $>60$ observations during the survey) was pooled together and extrapolated to estimate the population for specific habitat types. The population density was the estimated population divided by the extent of the study area with respect to the habitat types where the species is recorded (Wilson et al. 1996). However, for rare species like Swayne's hartebeest, or for less 
frequent species (i.e. $<60$ observations during the survey), all individuals were counted, thus the surveys were a mix of census and sample (Sutherland 2006). Although, there is no sufficient historical data on the abundance of the many of wildlife in the NSNP, time series records of Grant's zebra (Equus quagga), Swayne's hartebeest (Alcelaphus buselaphus swaynei) and livestock population from previous studies (e.g. Kelboro and Stellmacher 2012) were considered for the analysis as their population trend could serve as disturbance indicator of anthropogenic land use.

\section{Assessment of human activities}

Quantifying the intensity and distribution of human impacts in different habitat types of NSNP was one of the primary objectives of this research. Accordingly, relevant data were collected on the distribution and abundance of human settlement (including house numbers and type), domestic animal sightings, livestock Karel and other infrastructure using field observation and Google Earth digital image. Human settlement within the park was described by house type of roofing material used as grass-roofed and tin-roofed, which reflects a temporary or permanent residence situation (Worden et al. 2003).

\section{Results}

\section{Habitat loss and fragmentation}

The results of landscape metrics analysis have shown major changes in the size, number, distance, spatial distribution and configuration of landscape fragments for different habitats at the class level. The composition of the forested area across the landscape has increased in terms of patch numbers (NP) from 169 in 1985 to 195 in 1995 but reduced to 165 in 2005 (showed relative recovery under the management of African Parks Foundation) and again rose to 641 in 2013 (Table 3). On the other hand, the mean patch size (MPS) of the forest has greatly decreased from 18.92 ha in 1985 to 12.81 ha in 1995 , again rose to 14.43 ha but decreased to 3.26 ha in 2013 . The grassland habitat has behaved in the same way as the forest patches did, in terms of habitat fragmentation where the number of patches has increased with reduced patch size. To that end, the mean number of patches for the grassland has increased from 441 in 1985 to 1126 in 2013, whereas, the mean patch size has decreased from 166.31 ha to 123.53 during the same period. These two habitats are considered important for the wildlife management in the Nech Sar National Park, nevertheless, both of them are extremely suffered from habitat disturbance and habitat fragmentation. Indeed, these habitats

Table 3 Class level landscape metrics for five habitat types at NSNP

\begin{tabular}{|c|c|c|c|c|c|c|c|c|}
\hline \multirow[t]{2}{*}{ Year } & \multirow[t]{2}{*}{ Habitat } & \multicolumn{7}{|c|}{ Landscape metrics } \\
\hline & & CA & PLAND & NP & MPS & MNN & MPFD & اנI \\
\hline \multirow[t]{5}{*}{1985} & Forest & 3197.70 & 9.65 & 169 & 18.92 & 204.13 & 1.058 & 63.41 \\
\hline & Shrubland & 4862.34 & 14.68 & 814 & 5.97 & 126.76 & 1.057 & 65.48 \\
\hline & Wooded grassland & 5972.04 & 18.03 & 1013 & 5.90 & 116.99 & 1.046 & 64.04 \\
\hline & Woodland & 8720.46 & 26.32 & 1089 & 8.01 & 105.88 & 1.053 & 74.76 \\
\hline & Grassland & 8740.71 & 26.38 & 441 & 19.82 & 166.31 & 1.052 & 49.81 \\
\hline \multirow[t]{5}{*}{1995} & Forest & 2497.23 & 7.53 & 195 & 12.81 & 133.36 & 1.056 & 47.37 \\
\hline & Shrubland & 5409.18 & 16.31 & 709 & 7.63 & 125.75 & 1.057 & 65.21 \\
\hline & Wooded grassland & 5599.80 & 16.89 & 963 & 5.82 & 122.56 & 1.051 & 48.85 \\
\hline & Woodland & $11,027.88$ & 33.26 & 1011 & 10.91 & 104.34 & 1.056 & 70.79 \\
\hline & Grassland & 6915.06 & 20.85 & 301 & 22.97 & 207.68 & 1.031 & 47.05 \\
\hline \multirow[t]{5}{*}{2005} & Forest & 2381.49 & 7.18 & 165 & 14.43 & 147.91 & 1.052 & 52.50 \\
\hline & Shrubland & 6763.95 & 20.40 & 782 & 8.65 & 116.16 & 1.053 & 77.52 \\
\hline & Wooded grassland & 4873.68 & 14.70 & 1331 & 3.66 & 119.84 & 1.053 & 81.30 \\
\hline & Woodland & 5788.62 & 17.46 & 1432 & 4.04 & 108.72 & 1.055 & 73.15 \\
\hline & Grassland & 4973.40 & 15.00 & 633 & 7.86 & 158.69 & 1.047 & 55.43 \\
\hline \multirow[t]{5}{*}{2013} & Forest & 2087.91 & 6.29 & 641 & 3.26 & 144.64 & 1.044 & 63.15 \\
\hline & Shrubland & 7975.98 & 24.03 & 1964 & 4.06 & 92.62 & 1.053 & 66.68 \\
\hline & Wooded grassland & 4872.51 & 14.68 & 3560 & 1.37 & 86.71 & 1.055 & 64.06 \\
\hline & Woodland & 7950.87 & 23.95 & 3166 & 2.51 & 83.84 & 1.046 & 65.61 \\
\hline & Grassland & 2278.62 & 6.86 & 1126 & 2.02 & 123.53 & 1.045 & 41.27 \\
\hline
\end{tabular}

CA class area (ha), PLAND \% of landscape, NP number of patches, MPS mean patch size (ha), MNN mean nearest-neighbor distance (m), IJl interspersion juxtaposition index (\%), MPFD mean patch fractal dimension 
tend to show a high degree of fragmentation where they are composed of more patches (higher NP), are more fragmented (low MPS, low CA) and are less well dispersed across the landscape (lower IJI) as compared to other habitat types across the study periods.

The measurement of MNN for the forest (204.13 $\mathrm{m}$ in $1985,133.36 \mathrm{~m}$ in $1995,147.9 \mathrm{~m}$ in $2005,144.64$ in 2013 ) and the grassland habitats $(166.31 \mathrm{~m}$ in $1985,207.68 \mathrm{~m}$ in $1995,158.69 \mathrm{~m}$ in $2005,123.58 \mathrm{~m}$ ) in all cases showed a highest value as compared to other habitats, which indicates a high degree of isolation among and between adjacent patches.

The values for the measure of the Interspersion Juxtaposition Index (IJI) were also lower for the forest and the grasslands as compared to other habitat types in all study periods. On the other hand, IJI indicates that the interspersion of available patch types is greatest in woodland and shrubland habitats, which indicate that this class occurs spatially and relatively evenly, interspersed with all other classes in the landscape.

The value of mean patch fractal dimension (MPFD) in this study was very low (1.031-1.058) for all class types under consideration, indicating that the landscape is influenced by anthropogenic land use and exhibit lower patch shape complexity.

\section{Population estimate and habitat use}

A total of 15 terrestrial large mammal species were recorded in the study area during the survey. However, the population estimate was performed for eight terrestrial mammalian species as the others are excluded by DISTANCE software due to their rare or less frequent distribution (i.e. $<60$ observations during the survey) (Fig. 3).

The overall population estimate of these eight terrestrial mammalian species has shown a significant difference between the wet and dry seasons $\left(\chi^{2}=1184, d f=7\right.$, $P<0.05)$. At individual species level also except black and white colobus (Colobus polykomos dollmani) and Vervet monkey (Cercopithecus aethiops), the population estimates of all species under Table 4 has shown a significant difference between the count of wet and dry seasons.

The population count of Grant's zebra (E. quagga) for wet and dry seasons for NSNP was 2500 and 1821 heads, respectively. The total population for Grant's zebra was estimated at $2161 \pm 480$ individuals, and the mean population density was estimated at $42 \pm 9 / \mathrm{km}^{2}$ which is distributed across the grassland and wooded grassland habitats with the major portion of (63\%) of Grant's zebras' population was distributed in the grassland habitat and $37 \%$ in the wooded grassland (Table 5) which shared the same habitat with Grant's gazelle (Gazella granti).

For Grant's gazelle (G. granti), an average of 2485 and 1814 individuals were recorded during wet and dry seasons, respectively. The total population of Grant's gazelle was estimated at $2150 \pm 474$ individuals, and the mean population density was estimated at $42 \pm 5 / \mathrm{km}^{2}$. Grant's gazelle was confined mainly in the grassland and wooded grassland habitats with the major portion (77\%) of the population were distributed in the grassland and 23\% in the wooded grassland.

The population count for Greater kudu (Tragelaphus strepsiceros) during the wet and dry season was 3764 and

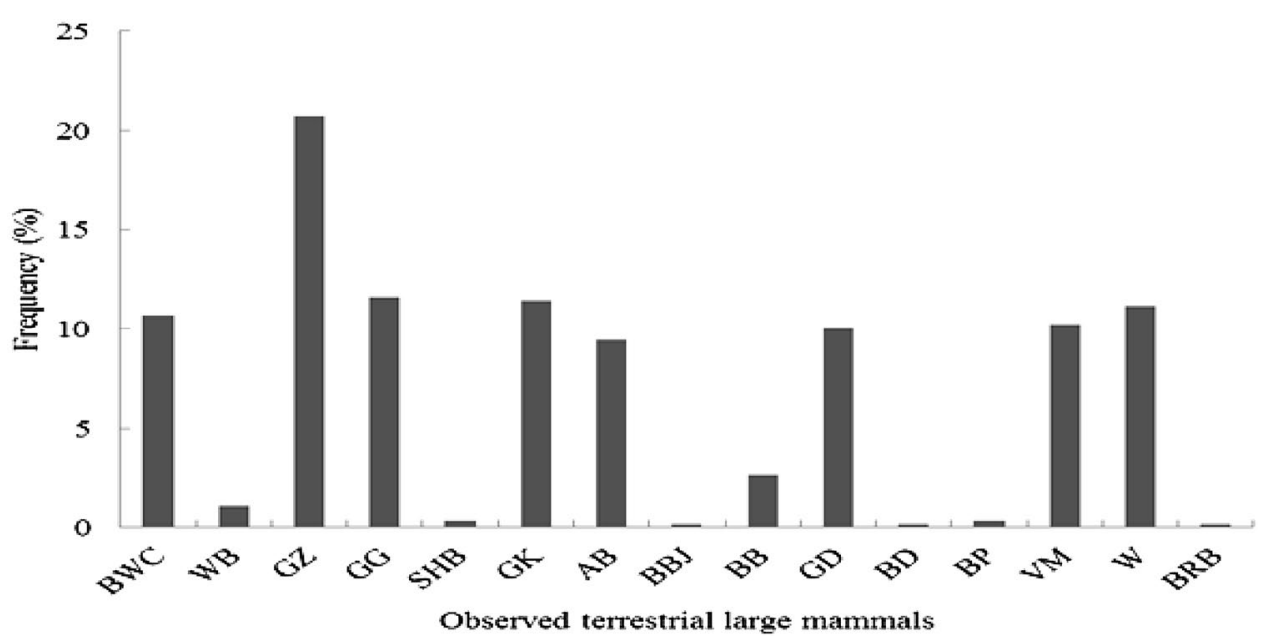

Fig. 3 Frequency distribution of observed terrestrial large mammals of NSNP. BWC black and white colobus, WB Waterbuck, GZ Grant's zebra, GG Grant's gazelle, SHB Swayne's hartebeest, GK greater kudu, AB Anubis baboon, BBJ black-backed jackal, BB Bushbuck, GD Guenther's dikdik, BD Bush duiker, BP Bush pig, VM Vervet monkey, WWarthog, BRB Bohor reedbuck 
Table 4 Population estimate of selected terrestrial large mammals in the NSNP (mean \pm SE)

\begin{tabular}{|c|c|c|c|}
\hline Species & Season & $\begin{array}{l}\text { Population } \\
\text { estimate } \\
\text { (N) }\end{array}$ & Density (D) $\mathrm{n} / \mathrm{km}^{2}$ \\
\hline \multirow[t]{3}{*}{ Grant's zebra } & Wet & 2500 & 48 \\
\hline & Dry & 1821 & 35 \\
\hline & Mean $\pm S D$ & $2161 \pm 480$ & $42 \pm 9$ \\
\hline \multirow[t]{3}{*}{ Grant's gazelle } & Wet & 2485 & 48 \\
\hline & Dry & 1814 & 35 \\
\hline & Mean $\pm S D$ & $2150 \pm 474$ & $42 \pm 5$ \\
\hline \multirow[t]{3}{*}{ Greater kudu } & Wet & 3764 & 24 \\
\hline & Dry & 3601 & 23 \\
\hline & Mean $\pm S D$ & $3683 \pm 115$ & $24 \pm 1$ \\
\hline \multirow[t]{3}{*}{ Black and white colobus } & Wet & 227 & 11 \\
\hline & Dry & 233 & 12 \\
\hline & Mean $\pm S D$ & $230 \pm 4$ & $12 \pm 0.2$ \\
\hline \multirow[t]{3}{*}{ Anubis baboon } & Wet & 1603 & 9 \\
\hline & Dry & 742 & 4 \\
\hline & Mean $\pm S D$ & $1173 \pm 609$ & $7 \pm 3$ \\
\hline \multirow[t]{3}{*}{ Vervet monkey } & Wet & 418 & 21 \\
\hline & Dry & 468 & 23 \\
\hline & Mean $\pm S D$ & $443 \pm 35$ & $22 \pm 1$ \\
\hline \multirow[t]{3}{*}{ Warthog } & Wet & 2276 & 14 \\
\hline & Dry & 1400 & 9 \\
\hline & Mean $\pm S D$ & $1838 \pm 619$ & $12 \pm 4$ \\
\hline \multirow[t]{3}{*}{ Guenther's dikdik } & Wet & 8823 & 43 \\
\hline & Dry & 5379 & 26 \\
\hline & Mean \pm SD & $7101 \pm 2435$ & $35 \pm 12$ \\
\hline
\end{tabular}

3601 respectively. The total population for Greater kudu was estimated at $3683 \pm 115$ and the mean population density was estimated at $24 \pm 1 / \mathrm{km}^{2}$. Greater kudu has a relatively wide distribution as compared to Grant's zebra and Grant's gazelle (G. granti). It has been distributed in the grassland, wooded grassland and woodland habitats where the majority of the population $(41 \%)$ was recorded in woodland.

The population count for Black and white colobus (Colobus polykomos dollmani) was 227 for the wet season and 233 for the dry season and entirely confined the forest habitat which makes a stable distribution at different seasons. The total population of Black and white colobus was estimated at $230 \pm 4$ and the density was $12 \pm 0.2$ / $\mathrm{km}^{2}$.

The population count of Anubis baboon (Papio anubis) was recorded as 1603 individuals for the wet season and 742 for the dry season. The spatial distribution was also relatively better as compared to other terrestrial large mammals where it was distributed across four habitats (forest, wooded grassland, woodland, and grassland) and the major portion $(63 \%)$ was recorded in the wooded land. The total population of Anubis baboon was recorded as $1173 \pm 609$ with the mean density of $7 \pm 3$ / $\mathrm{km}^{2}$ indicating having a wide range of home range and habitat association.

The population count of Vervet monkey (Cercopithecus aethiops) was 418 for the wet season and 468 individuals for the dry season. It was entirely confined on forest habitat and its total population was estimated at $443 \pm 35$ and a population density of $22 \pm 1 / \mathrm{km}^{2}$.

The population count of Warthog (Phacochoerus africanus) for the wet and dry season was 2276 and 1400 individuals respectively. Warthog was distributed across the forest, wooded grassland and woodland habitats where the major portion (52\%) of the population was recorded in the woodland. The total population of Warthog was estimated at $1838 \pm 619$ with a population density of $12 \pm 4 / \mathrm{km}^{2}$.

The population count of Guenther's dikdik (Madoqua guentheri) was 8823 for the wet season 5379 individual for the dry season and distributed across the habitats of shrubland, wooded grassland and woodland with the major portion $(40 \%)$ of the population was recorded in the shrubland followed by $38 \%$ in woodland. The total population of Guenther's dikdik was estimated at $7101 \pm 2435$ with a population density of $35 \pm 12 / \mathrm{km}^{2}$.

On the other hand, other encountered species such as Swayne's hartebeest (Alcelaphus buselaphus swaynei), Waterbuck (Kobus ellipsiprymnus), Bohor reedbuck (Redunca redunca), Black-backed jackal (Canis mesomelas), Bushbuck (Tragelaphus scriptus), Bush duiker (Sylvicapra grimmia) and Bush pig (Potamochoerus larvatus) were seen in the rarest count with few observations in the park where the DISTANCE software could not be able to estimate the population. However, special attention has been given for Swayne's hartebeest by the office of NSNP and daily monitoring activities were put in place. Based on the information from the NSNP archive and based on 2013 count, the total population of the endangered Swayne's hartebeest which was considered as a keystone species for the establishment of Nech Sar National Park, was only four (4) individuals, with one adult male and three adult females.

\section{Anthropogenic activities}

Human impacts are negligible in the shrublands along the God's bridge between the two lakes of Abaya and Chamo (Fig. 4) whereas, human pressure in the form of agriculture (crop cultivation and livestock production) and settlement was higher at the eastern part of the park, particularly in the Sermele valley and in the Nech Sar plain. On the other hand, human pressure in the form of fuelwood and construction wood collection was higher 
Table 5 Observation of different species in a different habitat type of NSNP

\begin{tabular}{|c|c|c|c|c|c|c|c|}
\hline \multirow[t]{2}{*}{ Species } & \multirow[t]{2}{*}{ Season } & \multicolumn{5}{|c|}{ Population distribution in different habitats } & \multirow[t]{2}{*}{ Total population } \\
\hline & & FR & SL & WGL & WL & GL & \\
\hline \multirow[t]{3}{*}{ Grant's zebra } & Wet & - & - & 915 & - & 1585 & 2500 \\
\hline & Dry & - & - & 682 & - & 1139 & 1821 \\
\hline & Mean \pm SD & - & - & $799 \pm 165$ & - & $1362 \pm 315$ & $2161 \pm 480$ \\
\hline \multirow[t]{3}{*}{ Grant's gazelle } & Wet & - & - & 363 & - & 2122 & 2485 \\
\hline & Dry & - & - & 617 & - & 1197 & 1814 \\
\hline & Mean $\pm S D$ & - & - & $490 \pm 180$ & - & $1660 \pm 654$ & $2150 \pm 474$ \\
\hline \multirow[t]{3}{*}{ Greater kudu } & Wet & - & - & 1584 & 996 & 1184 & 3764 \\
\hline & Dry & - & - & 1018 & 1991 & 592 & 3601 \\
\hline & Mean \pm SD & - & - & $1301 \pm 400$ & $1494 \pm 704$ & $888 \pm 419$ & $3683 \pm 115$ \\
\hline \multirow[t]{3}{*}{ Black and white colobus } & Wet & 227 & - & - & - & - & 227 \\
\hline & Dry & 233 & - & - & - & - & 233 \\
\hline & Mean \pm SD & $230 \pm 4$ & - & - & - & - & $230 \pm 4$ \\
\hline \multirow[t]{3}{*}{ Anubis baboon } & Wet & 100 & - & 204 & 991 & 308 & 1603 \\
\hline & Dry & 80 & - & 127 & 478 & 57 & 742 \\
\hline & Mean $\pm S D$ & $90 \pm 14$ & - & $166 \pm 54$ & $735 \pm 363$ & $183 \pm 177$ & $1173 \pm 609$ \\
\hline \multirow[t]{3}{*}{ Vervet monkey } & Wet & 418 & - & - & - & - & 418 \\
\hline & Dry & 468 & - & - & - & - & 468 \\
\hline & Mean \pm SD & $443 \pm 35$ & - & - & - & - & $443 \pm 35$ \\
\hline \multirow[t]{3}{*}{ Warthog } & Wet & 226 & - & 781 & 1269 & - & 2276 \\
\hline & Dry & 409 & - & 356 & 635 & - & 1400 \\
\hline & Mean \pm SD & $318 \pm 129$ & - & $569 \pm 301$ & $952 \pm 448$ & - & $1838 \pm 619$ \\
\hline \multirow[t]{3}{*}{ Guenther's dikdik } & Wet & - & 3333 & 1923 & 3567 & - & 8823 \\
\hline & Dry & - & 2345 & 1250 & 1784 & - & 5379 \\
\hline & Mean \pm SD & - & $2839 \pm 699$ & $1587 \pm 476$ & $2676 \pm 1261$ & - & $7101 \pm 2435$ \\
\hline
\end{tabular}

FR forest, SL shrubland, WGL wooded grassland, WL woodland, GL grassland

in the western parts of the park particularly at the Arba Minch forest.

The large concentration of settlements with grassroofed and tin-roofed houses within the protected area are aggregated in the grassland and wooded grassland habitats in the eastern parts of the park (Figs. 4a, b, 5). The forest, grassland, and the wooded grassland habitats have the highest quantifiable human impact. The types of illegally constructed houses in the NSNP were primarily mud and wood wall with grass roof but very recently tin-roofed houses are expanded within the protected area particularly in the grassland and wooded grassland habitats. Moreover, social institutions including schools, churches and health centers are established along with the residential areas.

Out of the recorded 1079 total houses built within the park $867(80.4 \%)$ were mud and wood with a grass roof which is constructed from local materials collected from within the park and 212 (19.6\%) were tin-roofed. House type is used as an indicator for sedentarization and the ratio tin and mud to grass houses $(0.24: 1)$ indicating permanency of human settlement and therefore, the high intensity of human impact on wildlife. Another indicator of human impact on the wildlife is fencing livestock Karel with respect to each household and a household is expected to have at least one Karel near to his residence. Accordingly, in this study about 771 cattle Karels were recorded with the ration of cattle Karel to house as 0.89:1 (Fig. 5).

\section{Discussions}

\section{Habitat loss and fragmentation}

The landscape change and landscape disturbance in the NSNP is attributed to anthropogenic land uses such as crop cultivation, wood and grass collection, livestock grazing and associated engagement in livelihood across the study period (Kelboro and Stellmacher 2012). This sociological change has contributed for an increased number of patches where a piece of habitat is further divided into several patches of smaller size. Decreasing in patch size (MPS, CA) and increasing in patch number (NP) are good indicators of anthropogenic land use disturbance and subsequent habitat fragmentation. Increased fragmentation of natural areas will also have 


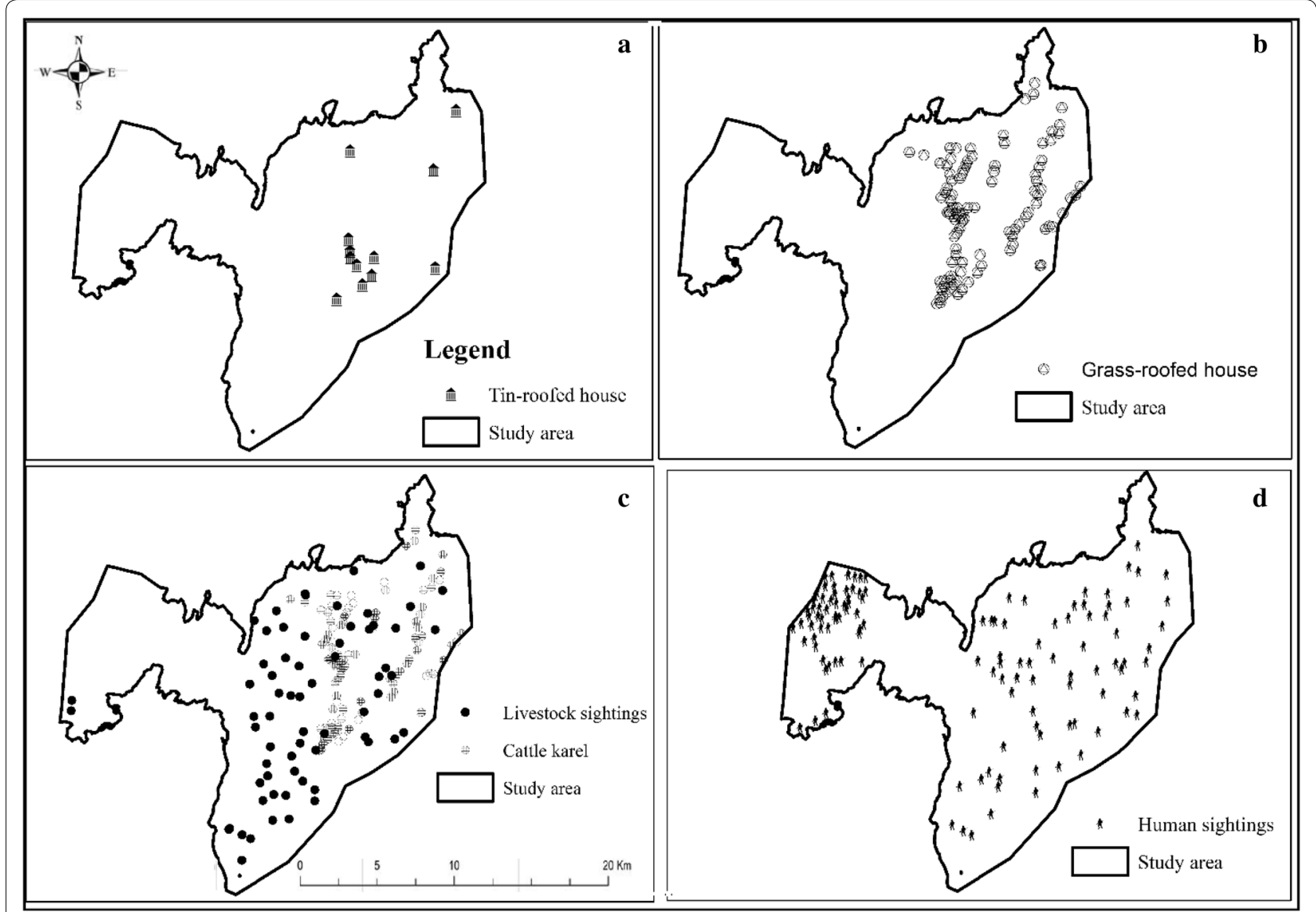

Fig. 4 Human land use in the Nech Sar National Park

a negative effect on threatened and endangered species (Narumalani et al. 2004; Tolessa et al. 2016) which is also reflected in this study that major changes in wildlife habitats through loss and fragmentation have negatively affected the abundance and distribution of key terrestrial large mammals of NSNP.

Determination of patch number and patch size has an essential implication on energy, nutrients, and species diversity based on the fact that larger patches generally hold a greater number of species than smaller patches (Lavers and Haines-Young 1993). When patches in the habitat are fragmented into smaller units, the density of wildlife population will likely tend to decrease and resulting in the risk of local species extinction (Farina 1998). Hence, habitat loss and fragmentation in the Nech Sar Plain has negatively affected the plain games especially the endangered Swayne's hartebeest to the point of local extinction.

Large isolation of habitat patches from the nearest adjacent patches could have an effect on population dynamics and species interactions in spatially subdivided populations (Kareiva 1990; Pinto-Ledezma and Rivero 2014; Cuke and Srivastava 2016) and such population may be influenced by their proximity to other subpopulations of the same or competing species (McGarigal and Marks 1995). Hence, determination and management intervention in maintaining a lower nearest-neighbor distance ( $\mathrm{MNN}$ ) between and among habitat patches in a protected area could have a preeminent role in the conservation efforts of endangered species (Lamberson et al. 1992; McKelvey et al. 1992).

The analysis of IJI measures for woodland and shrubland classes is reportedly greater than $65 \%$ in all study periods and it seems relatively evenly interspersed. IJI measures the patch adjacency and when it approaches 100 , it indicates that all patch types are equally adjacent to each other and when it approaches zero it indicates the distribution of unique patch adjacencies becomes uneven (McGarigal and Marks 1995).

Declining in MNN values is attributed to the combined result of the splitting of single large patches into two or more adjacent smaller patches that have low nearest neighbor distances and the emergence of new 


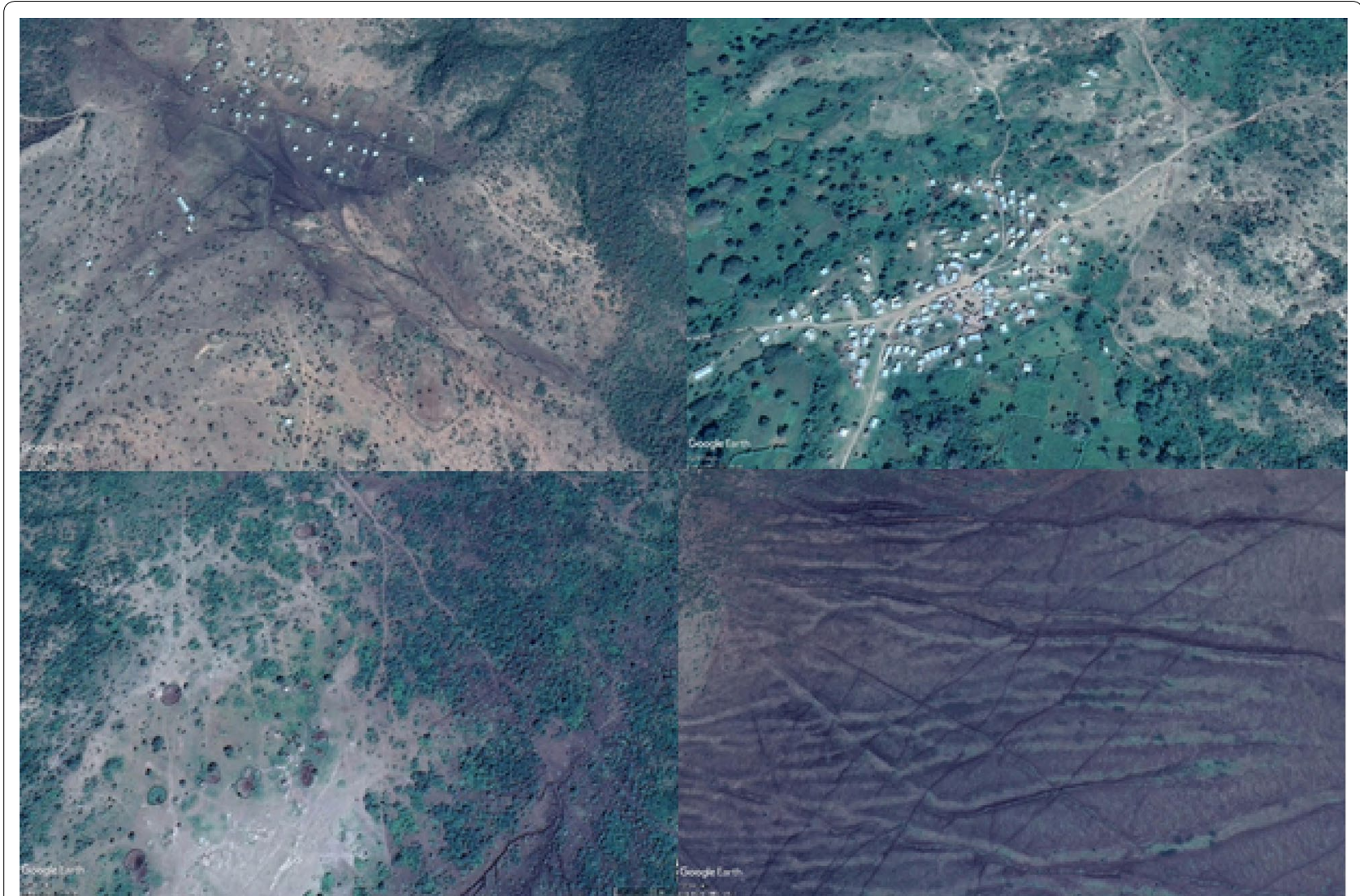

Fig. 5 Anthropogenic disturbances of habitats and associated land degradation at NSNP (Source: Google Earth Digital Image)

habitat in close proximity to existing habitat patches (Betts et al. 2003).

In reality, the value of the mean fractal dimension approaches one for shapes with simple perimeters and approaches two when shapes are more complex (McGarigal and Marks 1995). The principal premise for having higher value of MPFD close to two is that boundaries of natural land cover types often have complex shapes as compared to the human-disturbed landscapes such as settlement, agricultural fields, and livestock grazing areas (De Cola 1989; Krummel et al. 1987; O’Neill et al. 1988; Turner and Ruscher 1988). Thus, MPFD is a good landscape metrics used to quantify the complexity of patch shapes in ecosystem change analysis (Krummel et al. 1987; Lam 1990) and it is a good indicator of the degree of human disturbance on the landscape.

\section{Change in population size and habitat use of terrestrial large mammals}

The findings from this survey revealed that the population of Grant's zebra (E. quagga) has decreased from 6500 individuals in 1985 (Kirubel 1985) to 2161 in the present study based on the 2013 count. The obvious reason for the decrease in Grant's zebras' population might be that a large portion of Grant's zebra population has moved out of the park territory due to habitat disturbance. Currently, it is a usual feature of observing Swayne's hartebeests, Grant's gazelle (G. granti), Grant's zebra and domestic herbivores grazing together. Such patterns of competition lead to resource depletion in the grassland habitats and forced large wild herbivores particularly Grant's zebra to forage elsewhere out of the park. Doku et al (2006) reported that livestock is a major ecological competitor for feeding and habitat use of Grant's zebra in the NSNP.

Although there are no previous studies on the population trend of Grant's gazelle (G. granti) in NSNP, the evidences from the 2008 IUCN Antelope Specialist Group assessment report indicated that the population is decreasing in its native countries (Ethiopia, Kenya, Somalia, Sudan, Tanzania, and Uganda) due to agricultural expansion, livestock farming, nomadic grazing and hunting (IUCN 2013). However, at a local level, the population count of Grant's gazelle in 2013 at NSNP (2150) is by far higher than the one recorded in Abijata-Shalla Lakes National Park (78) in 2012 (Yihune and Bekele 2012). 
Greater Kudu (Tragelaphus strepsiceros) has shown wider habitat use as compared to other big games such as Grant's zebra, Grant's gazelle, and Swayne's hartebeest. The greater kudu most often occurred in open woodland, grasslands and wooded grasslands but rarely occurred in the closed forest and shrubland. The reason for a wide distribution for Greater kudu as compared to the other angulates in the NSNP mainly related to the presence of preferred feed in these habitats, its ability to eat a greater variety of woody plant species that provide browse and get cover and protection (Vaughan et al. 2000; Eden 2006; Gray et al. 2007).

Primates such as Black and white colobus (Colobus polykomos dollmani) and Vervet monkeys (Cercopithecus aethiops) are dominantly used the forest habitat. A similar study from Kibale National Park, Uganda (Daphne and Colin 2000) reported that Black and white colobus and Vervet monkey are consistently found in the forest habitat. Thus, the destruction of forest habitat has greatly affected the population of the primates as compared to the population of ungulates in the NSNP.

The findings revealed that the shrubland habitat is the list preferred habitat by the terrestrial large mammals in the study area where only the species of Guenther's dikdik was recorded during this survey. This result is in line with other studies (e.g. Eden 2006; Stuart and Stuart 2000; Mengesha and Bekele 2008) who reported that terrestrial large mammals frequently used woodland, wooded grasslands, open grasslands and the least frequent use of closed forest and shrubland.

\section{Anthropogenic activities in NSNP}

Previously scattered grass-roofed residences are recently mixed with dense tin-roofed houses within the protected area. The materials used for house construction are indicators for permanence and may serve as a surrogate for mobility and its correlate, intensity of human disturbance (Worden et al. 2003). Moreover, social institutions including schools, churches and health centers are established along with the residential areas. The establishment of these social institutions is also used as an indicator for sedentarization and the ratio tin and mud to grass houses (0.24:1) in this study suggests the permanency of human settlement (Worden et al. 2003) and therefore, the high intensity of human impact on wildlife.

The number of cattle Karel is also used to estimate the cattle population living within the protected area. In the Guji culture, since cattle are not counted directly, we tried to relate the cattle number to the recorded cattle Karel and hence, based on the estimate of Kelboro and Stellmacher (2012) the average cattle population per household for 2010 was 82 cattle with a total of about 43,542 cattle lived inside the park and grazed in the grassland plains which this figure was reported as 32,922 before 5 years i.e. in 2005. Thus, this average was taken for 2013 per the above number of cattle shelter and estimated that about 63, 222 cattle lived and grazed in the Nech Sar plain and associated wooded grasslands. This result indicates that the cattle population has increased by $50 \%$ between 2005 and 2013 within the Nech Sar National Park.

Fuelwood and construction wood collection have been also daily activities that greatly affect the wildlife habitats of Nech Sar National Park. For instance, the urban population in Arba Minch town is dominantly relaying on the park resources particularly for biomass energy and construction wood. In line with this effect, Fetene et al. (2012) reported that 147 persons were entered into the park to collect fuelwood and construction.

\section{Impacts of anthropogenic activities on terrestrial large mammals}

Analysis of long-term data from different sources and own field survey has shown rapid declines for key wildlife species in NSNP. Since, there is no sufficient historical data on the abundance and distribution of large mammals in the Nech Sar National Park, its difficult to show the trend of population estimate of all encountered species over time. Actually, Kelboro and Stellmacher 2012) has compiled a population trend of Grant's zebra ( $E$. quagga) for some years based on other previous studies and have reported that the population of Grant's zebra has shown a fluctuating trend as from 400 in 1970 (Bolton 1973) rise to 6500 in 1985 (Kirubel 1985), decreased to 3000 in 1995 increased to 4500 in 2002 (Doku et al. 2007) but back down to 2161 in the present study based on the 2013 count. Population decrease is attributed to severe competition by domestic livestock for grazing resources in the Nech Sar Plain. Previous studies in other protected areas of Ethiopia like Bale Mountains National Park (Stephens et al. 2001) and Awash National Park (Belay et al. 2012) reported that an increase in livestock population has competitively excluded the large mammalian wildlife from their natural range, influenced their habitat use and caused to decline in their population.

Sudden death also reported as another factor for the decline in Grant's zebra (E. quagga) population. For instance, a death of 35 Grant's zebra was reported in April and May 2007 (source: NSNP archive) due to water contamination in Lake Chamo where the massive fish kill was also reported overnight in the same year and season. Such types of catastrophic effects have been experienced once in three decades where mass Grant's zebra and fish kill was reported in 1978 (Belay and Wood 1982).

Moreover, in this study based on the 2013 count, the total population of the endangered Swayne's hartebeest 
which was considered as a keystone species for the establishment of Nech Sar National Park, was only four (4) individuals, with one adult male and three adult females. According to the historical data as compiled by Kelboro and Stellmacher (2012), the population of Swayne's hartebeest has significantly decreased between the periods of 1970 and $2013\left(r^{2}=0.91 ; p<0.01\right)$ from 130 individuals in 1967 (Blower 1968), to 100 in 1972 (Bolton 1973), to 40 in 1992 (Duckworth et al. 1992), to 35 in 2008 (Vymyslicka et al. 2010; Datiko and Bekele 2011), to 12 in 2010 (Mamo et al. 2012), to four (4) in 2012 and locally extinct between 2017 and 2018 based on the Nech Sar National Park Office information as there is no record on this species in the past 3 years. Therefore, a significant decline in the trend and inexistent of Swayne's hartebeest from the Nech Sar National Park is an indicator for the serious threat of the habitat and associated degradation of the wildlife due to anthropogenic landscape disturbance in the past couple of years. Therefore, in this study plain games are noticed as the most sensitive wildlife to anthropogenic disturbances and the decline in Swayne's hartebeest population is directly linked to the degradation of grassland habitat (Fig. 6). Based on yearly time series data (Fetene et al. 2016) has reported that grassland habitat has been declined by $12.7 \%$ between 1985 and 1995, by $20.3 \%$ between 1995 and 2005, by $67.3 \%$ between 2005 and 2013 and showed a net decrease by $77.2 \%$ between
1985 and 2013. The landscape disturbances and resultant impacts on the grassland habitat have clearly reflected in the loss of Swayne's hartebeest population of NSNP.

Generally, the landscape disturbance and loss in wildlife population in the Nech Sar National Park could be attributed to the growth of the human population in and around the park. For instance, a population census in the Nech Sar National Park between 1973 and 1975 was reported as 1222 persons living in 302 houses with a livestock population of 5897 heads, mostly cattle where 502 of the persons lived in permanent villages whereas others were pastoralists (Schubert 2015). However recent studies in the park have revealed that about 3500 households with more than 50,000 livestock are living in and in an immediate vicinity of the park which cause serious damage on vegetation and loss of wildlife population of the park through settlement, overgrazing, and deforestation (Marye 2014). Similarly, the growth of the urban population in Arba Minch town has created series degradation on the park with greater pressure on the groundwater forest of Arba Minch. The population of Arba Minch in 1964 was only between 1500 to and 2000 people (Elias 2003). However, the number of population has increased to 23,032 in 1994 census, 74,879 in 1994 census, 40,020 in 2007 census and 142,900 in 2015 projection (Brinkhoff 2016) and created unprecedented pressure on the wildlife habitats.

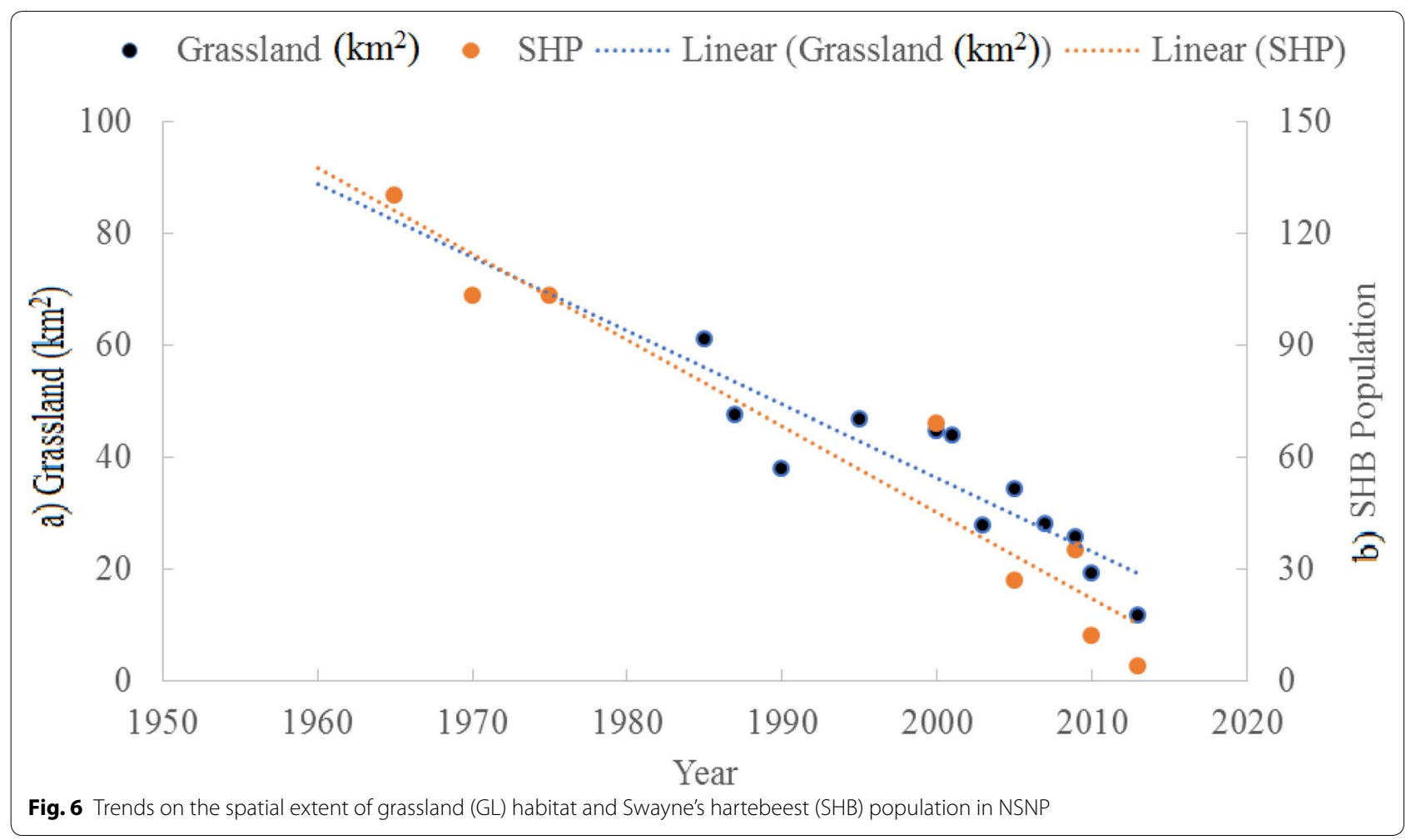




\section{Conclusions}

The finding revealed that anthropogenic disturbance of the landscape has resulted in extensive habitat change and a drastic decline of key wildlife species particularly extreme loss of Swayne's hartebeest in the NSNP over the past three decades. These changes are mainly related to habitat loss and habitat fragmentation due to deforestation, livestock production and residential expansion (tin-roofed, grass-roofed houses). The highest anthropogenic impacts were detected on the forest and grassland habitats. The habitat disturbance has also led to the loss of grazing, shelter, breeding and dispersal areas of the formerly habitats used by wildlife species and are the main reasons for the observed wildlife loss in the study area.

Since NSNP is established based on the IUCN category II conservation criteria, its management should be guided based on the international protected area conservation standards. However, the present condition of NSNP seems "an authorized wildlife reserve" where the communities are residing within the core area with their livestock. Moreover, social institutions including schools, churches and health centers are established along with the residential areas.

Therefore, the main priority in NSNP should be designing management strategies to restore the park as a fully functioning sustainable ecosystem and ensuring the social and economic sustainability of the local community. This intervention can be addressed by creating other means of livelihood, the supply of alternative energy, establishing basic infrastructure and relocating the community out of the park area. In this regard, a resettlement action plan (RAP) should be prepared that could ensure the community will not come back to the protected area for livelihood. Following the RAP program, the ecological restoration program within the protected area should be designed while making the community as a key participant starting from the planning to the implementation as well as put a clear benefit and revenue sharing mechanisms that could mainstream the local communities' interest and nature conservation.

\section{Abbreviations}

RAP: resettlement action plan; NSNP: Nech Sar National Park; IUCN: International Union for the Conservation of Nature; CA: core area; PLAND: percent of landscape; NP: number of patch; MPS: mean patch size; IJl: interspersion and juxtaposition index; MNN: mean near neighbor distance; MPFD: mean patch fractal dimension.

\section{Acknowledgements}

The authors gratefully acknowledge the financial support provided by the International Foundation for Science (IFS) Stockholm, Sweden, through a grant to Aramde Fetene Mengistu with grant number D5284-2, and for USGS for providing Landsat images free of charge for spatial metrics analysis.

\section{Authors' contributions}

Aramde Fetene and Kumelachew Yeshitela conceptualized the study. Aramde Fetene collected and analyzed the data, and wrote the draft manuscript; Ephrem Gebremariam edited and modified the structure of the manuscript. All authors read and approved the final manuscript.

\section{Funding}

This paper is prepared under the support of the International Foundation for Science (IFS) Stockholm, Sweden, through a grant to the first author with grant number D5284-2 to study habitat quality at Nech Sar National Park.

\section{Availability of data and materials}

Data is available with the corresponding author and will be provided if need

\section{Ethics approval and consent to participate}

The paper followed the ethics and consent to participate during the research work.

\section{Consent for publication}

All authors approved the manuscript for its publication.

\section{Competing interests}

The authors declare that they have no competing interests.

Received: 22 February 2019 Accepted: 23 May 2019

Published online: 31 May 2019

\section{References}

Anderson DR, Burnham KP, Crain BR (1978) A long-linear model approach to estimation of population size using the line transects sampling method. Ecology 59:190-193

Baillie JEM, Hilton-Taylor C, Stuart SN (2004) IUCN red list of threatened species: a global species assessment. IUCN, Cambridge

Belay A, Wood RB (1982) Limnological aspects of an algal bloom on Lake Chamo in Gamogofa administrative region of Ethiopia in 1978. SINET Ethiop J Sci 5:1-19

Belay S, Amsalu A, Abebe E (2012) Awash National Park, Ethiopia: use policy, ethnic conflict and sustainable resources conservation in the context of decentralization. Afr J Ecol 51:122-129

Bender D, Contreras T, Fahrig L (1998) Habitat loss and population decline: a meta-analysis of the patch size effect. Ecology 79:517-533

Betts MG, Franklin SE, Taylor RG (2003) Interpretation of landscape pattern and habitat change for local indicator species using satellite imagery and geographic information system data in New Brunswick, Canada. Can J For Res 33:1821-1831

Blom A, Van Zalinge R, Mbea E, Heitkonig IMA, Prins HHT (2004) Human impact on wildlife populations within a protected Central African forest. Afr J Ecol 42:23-31

Blower J (1968) The wildlife of Ethiopia. Oryx 9:276-285

Bolton M (1971) Ethiopia: last chance for Swayne's hartebeest. Biol Conserv 3(2):147-149

Bolton M (1973) Hartebeests in Ethiopia. Oryx 12:99-108

Borkowski J, Furubayashi K (1998) Seasonal and diet variation in group size among Japanese Sika deer in different habitats. J Zool 245:29-34

BrinkhoffT (2016) City population. https://www.citypopulation.de/Ethiopia. html. Accessed 14 May 2019

Bruner AG, Gullison RE, Rice RE, Fonseca GAB (2001) Effectiveness of parks in protecting tropical biodiversity. Science 291:125-128

Buckland ST, Anderson DR, Burnham KP, Laake JL (1993) Distance sampling: estimating abundance of biological populations. Chapman and Hall, London

Burnham KP, Andrson DR, Laake JL (1980) Estimation of density from line transect sampling of biological population. Wildl Monogr 72:1-202

Cardinale BJ, Srivastava DS, Duffy JE, Wright JP, Downing AL, Sankaran M, Jouseau C (2006) Effects of biodiversity on the functioning of trophic groups and ecosystems. Nature 443:989-992

Ceballos G, Ehrlich PR (2002) Mammal population losses and the extinction crisis. Science 296:904-907 
Clark DL (2010) An introduction to the natural history of Nech Sar National Park. Ethiopian Wildlife \& Natural History Society, Addis Ababa

Coulon A, Morellet N, Goulard M, Cargnelutti B, Angibault J, Hewison AJM (2008) Inferring the effects of landscape structure on roe deer (Capreolus capreo/us) movements using a step selection function. Landsc Ecol 23:603-614

Craigie ID, Baillie JEM, Balmford A, Carbone C, Collen B, Green R, Hutton JM (2010) Large mammal population declines in Africa's protected areas. Biol Conserv 143:2221-2232

Cuke M, Srivastava DS (2016) Divergent effects of tropical forest fragmentation and conversion on leaf litter decomposition. Landsc Ecol 31:1037-1050

Daphne AO, Colin AC (2000) Coping with forest fragmentation: the primates of Kibale National Park, Uganda. Int J Primatol 21:587-611

Datiko D, Bekele A (2011) Population status and human impact on the endangered Swayne's hartebeest (Alcelaphus buselaphus swaynei) in Nech Sar plains, Nech Sar National Park, Ethiopia. Afr J Ecol 49:311-319

De Cola L (1989) Fractal analysis of a classified Landsat scene. Photogramm Eng Remote Sens 55:601-610

Doku Y, Bekele A, Balakrishnan M (2006) Human impact on the plains zebra (Equus quagga) population in Nech Sar Plains, Nech Sar National Park, Ethiopia. Int J Ecol Environ Sci 32:137-142

Doku Y, Bekele A, Balakrishanan M (2007) Population status of plain Zebra (Equus quagga) in the Nech Sar National Park, Ethiopia. Trop Ecol 48:79-86

Duckworth JW, Evans MI, Safford RJ, Telfer MG, Timmins RJ, Zewdie C (1992) A survey of Nech Sar National Park, Ethiopia: report of the Cambridge Ethiopia ground-water forest expedition 1990. International council for bird Preservation study report No. 50, UK

Durant SM, Craft ME, Hilborn R, Bashir S, Hando J, Thomas L (2011) Long-term trends in carnivore abundance using distance sampling in Serengeti National Park, Tanzania. J Appl Ecol 48:1490-1500

Eden DG (2006) Habitat preference and status of the Greater kudu in Tembe Elephant Park. University of Pretoria, Capetown

Elias E (2003) Socio-economic data of agriculture and natural resource, agricultural development, Gamo Gofa Zone of SNNP

Estrada A, Raboy BE, Oliveira LC (2012) Agroecosystems and primate conservation in the tropics: a review. Am J Primatol 74:696-711

Fahrig L (1997) Relative effects of habitat loss and fragmentation on population extinction. J Wildl Manag 61:603-610

FAO (2012) Global forest resources assessment 2015-terms and definitions. Forest Resources Assessment Working Paper 180. Rome, Italy

Farina A (1998) Principles and methods in landscape ecology. Kluwer Academic Publishing, Dordrecht, p 256

Fetene A, Bekele T, Pananjay KT (2012) Impact of human activity on groundwater forest of Arba Minch. A case study from Ethiopia. Int J Basic Appl Sci 1:54-60

Fetene A, Hilker T, Yeshitela K, Prasse R, Cohen W, Yang Z (2016) Detecting trends in land use and landcover change of Nech Sar National Park, Ethiopia. Environ Manag 57:137-147

Fletcher RJJ, Hutto RL (2008) Partitioning the multi-scale effects of human activity on the occurrence of riparian forest birds. Landsc Ecol 23:727-739

Folke C, Carpenter S, Walker B, Scheffer M, Elmqvist T, Gunderson L, Holling CS (2004) Regime shifts, resilience, and biodiversity in ecosystem management. Ann Rev Ecol Evol Syst 35:557-581

Frankyates FRS (1971) Sampling method for census and survey, 3rd edn. Charles Griffin and Company Limited, London

Gray SS, Simpson TR, Baccus JT, Manning RW, Schwertner W (2007) Seasonal diet and foraging performance of greater kudu (Tragelaphus strepsicerus) in the Llano uplift of Texas. Wild Biol 13:75-88

Grimsdell JJR (1978) Ecological monitoring. Handbook No. 4. African Wildlife Foundation, Nairobi

Haddad NM, Brudvig LA, Clobert J, Davies KF, Gonzalez A, Holt RD, Collins CD (2015) Habitat fragmentation and its lasting impact on earth's ecosystems. Sci Adv 1:e1500052

Haines-Young R, Chopping M (1996) Quantifying landscape structure: a review of landscape indices and their application to forested landscapes. Prog Phys Geogr 20:418-445

Hockin D, Ounsted M, Gorman M, Hill D, Keller V, Barker MA (1992) Examination of the effects of disturbance on birds with reference to its importance in ecological assessments. J Environ Manag 36:253-286
IUCN (2013) IUCN red data list of threatened animals. International Union for Conservation of Nature, Cambridge

Kaly U, Pratt C, Howorth R (2002) Towards managing environmental vulnerability in small island developing states (SIDS). In: SOPAC Miscellaneous Report 461

Kareiva P (1990) Population dynamics in spatially complex environments: theory and data

Kelboro G, Stellmacher T (2012) Contesting the national park theorem? Governance and land use in Nech Sar National Park, Ethiopia. Center for development research, University of Bonn. Working Paper 104. Center for Development Research, University of Bonn

Kelboro G, Stellmacher T, Hoffmann V (2013) 'Conservationists' and the 'Local People' in biodiversity conservation: the case of Nech Sar National Park, Ethiopia. Ethiop J Soc Sci Humanit 9:29-55

Kilpatrick HJ, Lima KK (1999) Effects of archery hunting on movement and activity of female white-tailed deer in an urban landscape. Wildl Soc Bull 27:433-440

Kirubel T (1985) Nech Sar National Park preliminary report with particular reference to the distribution of large herbivores and major threats to the park resources. Ethiopian Wildlife Conservation Organization, Addis Ababa

Krummel JR, Gardner RH, Sugihara G, O'Neill RV, Coleman PR (1987) Landscape pattern in a disturbed environment. Oikos 48:321-324

Lam NSN (1990) Description and measurement of Landsat TM images using fractals. Photogramm Eng Remote Sens 56:187-195

Lamberson RH, McKelvey R, Noon BR, Voss C (1992) A dynamic analysis of northern spotted owl viability in a fragmented forest landscape. Conserv Biol 6:1-8

Lavers C, Haines-Young R (1993) Equilibrium landscapes and their aftermath: spatial heterogeneity and the role of new technology. In: Haines-Young $R$, Green D, Cousins S (eds) Landscape ecology and geographic information systems. Taylor \& Francis, London, pp 57-74

Lewis JG, Wilson RT (1979) The ecology of Swayne's hartebeest. Biol Conserv 15:1-12

MacLean MG, Congalton RGA (2015) Comparison of landscape fragmentation analysis programs for identifying possible invasive plant species locations in forest edge. Landsc Ecol 30:1241-1256

Mamo Y, Mengesha G, Fetene A, Shale K, Girma M (2012) Status of the Swayne's hartebeest (Alcelaphus buselaphus swaynei) metapopulation under land cover changes in Ethiopian protected areas. Int J Biodivers Conserv 4:416-426

Markovchick-Nicholls L, Regan HM, Deutschman DH, Widyanata A, Martin B, Noreke L, Hunt TA (2008) Relationships between human disturbance and wildlife land use in urban habitat fragments. Conserv Biol 22:99-109

Marye A (2014) Terms of reference on the boundary re-demarcation of Nech Sar National Park, Memo to EWCA, 10-2014

McGarigal K, Ene E (2012) FRAGSTATS 4.1: a spatial pattern analysis program for CategoricalMaps. http://www.umass.edu/landeco/research/fragstats/ fragstats.html. Accessed 12 Oct 2013

McGarigal K, Marks BJ (1995) FRAGSTATS: spatial pattern analysis program for quantifying landscape structure. General Technical Report PNW-GTR-351, USDA Forest Service, Pacific Northwest Research Station, Portland, OR

McKelvey K, Noon BR, Lamberson R (1992) Conservation planning for species occupying fragmented landscapes: the case of the northern spotted owl. In: Kingsolver J, Kareiva P, Hyey R (eds) Biotic interactions and global change. Sinauer Associates, Sunderland, pp 338-357

Megaze A, Belay G, Balakrishnan M (2012) Population structure and ecology of the African buffalo (Syncerus caffer Sparrman, 1779) in Chebera Churchura National Park, Ethiopia. Afr J Ecol 51:393-401

Mengesha G, Bekele A (2008) Diversity, distribution and habitat association of large mammals of Altish, North Gonder, Ethiopia. Acta Zoologica Sincia 54:20-29

Mesele Yihune and Afework Bekele (2012) Population status, feeding ecology and activity patterns of grant's Gazelle (Gazella granti) in Abijata-Shalla Lakes National Park, Ethiopia. Asian J Biol Sci 5:20-29

Moss CJ (2005) The demography of an African elephant (Loxodonta africana) population in Amboseli, Kenya. J Zool 255:145-154

Nagendra H (2001) Using remote sensing to assess biodiversity. Int J Remote Sens 22:2377-2400

Nagendra H, Rocchini D (2008) High resolution satellite imagery for tropical biodiversity studies: the devil is in the detail. Biodivers Conserv $17: 3431-3442$ 
Nandy S, Singh C, Das KK, Kingma NC, Kushwaha SPS (2015) Environmental vulnerability assessment of eco-development zone of Great Himalayan National Park, Himachal Pradesh, India. Ecol Ind 57:182-195

Narumalani S, Mishra DR, Rothwell RG (2004) Change detection and landscape metrics for inferring anthropogenic processes in the greater EFMO area. Remote Sens Environ 91:478-489

Ndhlovu DE, Balakrishnan M (1991) Large herbivores in Upper Lupande Game Management Area, Luangwa Valley, Zambia. Afr J Ecol 29:93-104

Njoroge P, Yego R, Muchane M, Githiru M, Njeri T, Giani A (2009) A Survey of the large and medium sized mammals of Arawale National Reserve, Kenya. J East Afr Nat Hist 98:119-128

Norton-Griffiths M (1978) Counting animals. Handbook No. 1, 2nd edn. African Wildlife Foundation, Nairobi

O'Neill RV, Krummel JR, Gardner RH, Sugihara G, Jackson B, DeAngelis DL, Milne BT, Turner MG, Zygmut B, Christensen SW, Dale VH, Graham RL (1988) Indices of landscape pattern. Landsc Ecol 1:153-162

Ogutu JO, Piepho HP, Dublin HT, Bhola N, Reid RS (2009) Dynamics of MaraSerengeti ungulates in relation to land use changes. J Zool 278:1-14

Paton P (1994) The effect of edge on avian nest success: how strong is the evidence? Conserv Biol 8:17-26

Pinto-Ledezma JN, Rivero MML (2014) Temporal patterns of deforestation and fragmentation in lowland Bolivia: implications for climate change. Clim Change 127:43-54

Presley SJ, Willing MR, Castro-Arellano I, Weaver SC (2009) Effects of habitat conversion on temporal activity patterns of phyllostomid bats in lowland Amazonian rain forest. J Mammalian Biol 90:210-221

Saberwal VK, Chhatre A (2003) The Parvati and the Tragopan: conservation and development in the Great Himalayan National Park. Himalia Res Bul 21:79-88

Said MY, Ogutu OJ, Kifugo SC, Makui O, Reid RS, de Leeuwa J (2016) Effects of extreme land fragmentation on wild life and livestock population abundance and distribution. J Nat Conserv 34:151-164

Scholte P (2011) Towards understanding large mammal population declines in Africa's protected areas: a West-Central African perspective. Trop Conserv Sci 4:1-11

Schubert A (2015) Awash and Nechisar National Parks, Ethiopia: a situation and SWOT analysis in Ethiopia. For the GIZ Biodiversity Conservation Program. Presented Addis Ababa. Short-term Consultant for GIZ

Southworth J, Nagendra H, Tucker C (2002) Fragmentation of a landscape: incorporating landscape metrics into satellite analyses of land-cover change. Landsc Res 27:253-269

Stephens PA, d'Sa CA, Sillero-Zubiri C, Leader-Williams N (2001) Impact of livestock and settlement on the large mammalian wildlife of Bale Mountains National Park, Southern, Ethiopia. Biol Conserv 100:307-322
Stuart C, Sturat T (2000) Field guide to the large mammals of Africa. Struik Publisher, Cap town, p 318

Sutherland WJ (2006) Ecological census techniques: a handbook, 2nd edn. Cambridge University Press, Cambridge

Svialek BJ (2008) Use of GIS technologies in biodiversity conservation: case study of vegetation and soil mapping in Nech Sar National Park, Ethiopia. M.Sc. Thesis, Czech University of Life Science, Prague

Tolessa T, Senbeta F, Kidane M (2016) Landscape composition and configuration in the central highlands of Ethiopia. Ecol Evol 6:7409-7421

Turner MG, Ruscher CL (1988) Change in landscape pattern in Georgia, USA. Landsc Ecol 1:241-251

Vaughan T, Ryan TM, Czaplewski NJ (2000) Mammalogy, 4th edn. Harcourt College Publisher, New York, p 565

Vymyslicka P, Hejcmanova P, Antonínová M, Stejskalova M, Svitále J (2010) Daily activity pattern of the endangered Swayne's Hartebeest (Alcelaphus buselaphus swaynei Sclater, 1892) in the Nech Sar National Park, Ethiopia. Afr J Ecol 49:246-249

White $F$ (1983) Vegetation of Africa - a descriptive memoir to accompany the UNESCO/AETFAT/UNSO vegetation map of Africa; Natural resources research report XX; U. N. Educational, Scientific and Cultural Organization; 7 Place de Fontenoy, 75700 Paris, France

Wiens JA (1990) Habitat fragmentation and wild life populations: the importance of autecology, time and landscape structure. In: Trans. 19th IUGB congress, pp 381-391

Wilcove DS, Rothstein D, Dubow J, Phillips A, Losos E (1998) Quantifying threats to imperiled species in the United States. Bioscience 48:607-615

Wilcox BA (1982) In-situ conservation of genetic resources: determinants of minimum area requirements. In: Mcneely JA, Miller KR (eds) National parks, conservation and development - the role of protected areas in sustaining society. Smithsonian Institution, Washington, DC, pp 639-647

Wilson DE, Cole FR, Rudran JDR, Foster M (1996) Measuring and monitoring biological diversity. Standard methods for mammals. Smithsonian Institution Press, Washington DC

Worden J, Reid R, Gichohi H (2003) Land use impact on large wildlife and livestock in the swamp of the Greatest Amboseli ecosystem, Kajiado district, Kenya. LUCID working paper series number: 27

\section{Publisher's Note}

Springer Nature remains neutral with regard to jurisdictional claims in published maps and institutional affiliations.

\section{Submit your manuscript to a SpringerOpen ${ }^{\circ}$ journal and benefit from:}

- Convenient online submission

- Rigorous peer review

- Open access: articles freely available online

- High visibility within the field

- Retaining the copyright to your article

Submit your next manuscript at springeropen.com 